\title{
Evaluating Healthy Corner Stores: A Survey of Assessment Tools Used in the San Francisco Bay Area, 2016
}

\section{Benjamin Chrisinger, $\mathrm{PhD}^{1}$}

\begin{abstract}
Suggested citation for this article: Chrisinger B. Evaluating Healthy Corner Stores: A Survey of Assessment Tools Used in the San Francisco Bay Area, 2016. Prev Chronic Dis 2017;14:170002. DOI: https://doi.org/10.5888/pcd14.170002.
\end{abstract}

\section{PEER REVIEWED}

\section{Abstract}

Stakeholders from healthy corner store programs in the San Francisco Bay Area convened in November 2015 to discuss the future of programmatic and collaborative efforts. This study's objective, to gather and synthesize the types of evaluation tools used in the 9 -county region, was identified as one of several priorities. Tools were collected via an online survey in July 2016, and data were extracted for comparison, including data on the number and types of food items, nutritional standards, and store characteristics. Twenty-five evaluation tools were collected, and differences were found in nutritional standards, terminology, and use of validated measures. Discrepancies between evaluation tools should be reconciled to make robust regional comparisons.

\section{Objective}

Across the United States, programs have been implemented among corner store retailers to improve the availability of healthy food options, especially in low-income areas without access to larger food retailers (1). Although many initiatives are evaluated at the local level, various tools and methods are used, challenging efforts to consider regional effects or collaborations (2-5). Various corner store programs exist in the 9 San Francisco Bay Area counties (Alameda, Contra Costa, Marin, Napa, San Francisco, San Mateo, Santa Clara, Solano, and Sonoma). Our objective was to catalog and synthesize the types of information collected by evaluations of these programs.

\section{Methods}

In November 2015, a meeting of program managers of Bay Area healthy corner stores and other stakeholders agreed on the need to understand when, where, and how evaluations are conducted. As an exploratory step, an online survey was developed and sent to all 77 attendees in July 2016 to collect and classify the types of evaluations being used. Respondents were encouraged to upload all relevant evaluation tools with their completed online study survey. In addition to uploading the evaluation tool, each respondent was asked to provide information on when the tool was used, the scope of the tool, whether it was from a standardized source and externally validated or developed by the local stakeholder, kinds of information collected (eg, prices, availability), and method of data collection (eg, interview, paper/tablet-based audit). Responses and evaluation tools were accepted through August 2016.

Survey responses were collected and organized. Several types of data were extracted from the evaluation tools. These included data on food items and nutritional standards and store characteristics, such as the number of registers in the store and whether the store participated in federal food assistance programs. Evaluation tools were classified into 3 categories according to the method used: instore observation or audit, consumer interview, and owner or manager interview. Evaluation tools were also coded by the number of items assessed in 7 food categories (dairy, protein, grain, fruit and vegetable, snack, beverage, and other food), nonfood goods or services sold, and store characteristics. All categories were divided into subcategories; for example, dairy was subcategorized by milk (eg, 1\%, skim, whole, flavored/unflavored), milk alternatives (eg, soy beverages, almond milk), and other dairy items (eg, yogurt, cheese) (Box). Descriptive statistics were generated for type of method used, category, and subcategory. Results were also presented to a group of healthy food retail stakeholders in the San Francisco area for additional refining in December 2016. 


\section{Box. Examples of Terminology Used in San Francisco Bay Area Healthy Corner Store Evaluation Tools by Categories and Subcategories of Food and Beverage Items, 2016}

\begin{tabular}{|c|c|}
\hline $\begin{array}{l}\text { Category / } \\
\text { Subcategory }\end{array}$ & Examples of Terminology \\
\hline \multicolumn{2}{|l|}{ Dairy } \\
\hline Milk & $\begin{array}{l}\text { Low-fat or skim milk, } 1 \% \text { milk, } 2 \% \text { milk, whole milk, } \\
\text { flavored, nonflavored, no sugar added }\end{array}$ \\
\hline $\begin{array}{l}\text { Milk } \\
\text { alternatives }\end{array}$ & $\begin{array}{l}\text { Milk alternatives, lactose-free/nondairy beverage, soy } \\
\text { beverage, soy products, almond milk, flavored, } \\
\text { nonflavored, no sugar added }\end{array}$ \\
\hline Other & Yogurt, cheese, butter, ice cream \\
\hline \multicolumn{2}{|l|}{ Protein } \\
\hline Meat & $\begin{array}{l}\text { Red meat, ground meat, chicken, poultry, fish, other } \\
\text { meat }\end{array}$ \\
\hline Other protein & Nut butter, eggs, legumes, tofu \\
\hline \multicolumn{2}{|l|}{ Grain } \\
\hline Cereal & Cereal \\
\hline Whole grains & Dried whole grain, whole grains, dry foods \\
\hline Pasta/noodles & Pasta, whole-grain pasta or noodles \\
\hline Bread & $\begin{array}{l}\text { Bread, whole-wheat bread, } 100 \% \text { whole-grain bread, } \\
\text { white bread, gluten-free bread, nonflour tortilla, tortilla } \\
\text { corn, tortilla wheat, tortilla flour, pita bread, sourdough } \\
\text { bread, pan dulce, bagels, fresh French bread }\end{array}$ \\
\hline \multicolumn{2}{|c|}{ Fruits and vegetables } \\
\hline Vegetables & $\begin{array}{l}\text { Canned vegetables, canned vegetables or soup, fresh } \\
\text { vegetables, frozen vegetables }\end{array}$ \\
\hline $\begin{array}{l}\text { Fruits and } \\
\text { vegetables }\end{array}$ & $\begin{array}{l}\text { Frozen fruits and vegetables, fresh fruits and } \\
\text { vegetables, dried and canned fruits and vegetables; } \\
\text { produce }\end{array}$ \\
\hline Fruits & Dried fruit, fruit cups, fresh fruit, canned fruit \\
\hline \multicolumn{2}{|l|}{ Snack food } \\
\hline Snacks & $\begin{array}{l}\text { Healthy snacks, snacks, healthy snacks/baked goods } \\
\text { salty, healthy snacks/baked goods sweet, salty snacks }\end{array}$ \\
\hline Bars & $\begin{array}{l}\text { Energy and power bars, granola and cereal bars, } \\
\text { granola bars, cereal bars }\end{array}$ \\
\hline Nuts/seeds & Nuts, nuts/seeds, nuts seeds and trail mix no candy \\
\hline Other snacks & $\begin{array}{l}\text { Granola; trail mix with candy, hummus packs, popcorn, } \\
\text { rice cakes }\end{array}$ \\
\hline Jerky & Dried meat/jerky, beef jerky \\
\hline Candy & Gum and mints, candy, candy/gumballs \\
\hline Desserts & Sweet desserts, cookies and cakes, cookies \\
\hline Chips/pretzels & Pretzels, chips and pretzels, chips \\
\hline \multicolumn{2}{|l|}{ Beverages } \\
\hline Water & Water/seltzer, flavored water, water \\
\hline Juice & $100 \%$ fruit juice, juices \\
\hline
\end{tabular}

\begin{tabular}{|l|l|}
\hline $\begin{array}{l}\text { Category / } \\
\text { Subcategory }\end{array}$ & \multicolumn{1}{|c|}{ Examples of Terminology } \\
\hline $\begin{array}{l}\text { Nonsugar } \\
\text { sweetened }\end{array}$ & $\begin{array}{l}\text { Coconut water, unsweetened beverages, unsweetened } \\
\text { tea, diet/noncaloric beverages, coffee }\end{array}$ \\
\hline $\begin{array}{l}\text { Sugar } \\
\text { sweetened }\end{array}$ & $\begin{array}{l}\text { Sports drink, energy drink, sweetened beverages, } \\
\text { sugar-sweetened beverages, soda }\end{array}$ \\
\hline Alcohol & Alcohol \\
\hline Other foods & Frozen healthy meals, frozen meals \\
\hline Frozen meals & $\begin{array}{l}\text { Baby food, smoothies, staple groceries, prepared foods, } \\
\text { canned products }\end{array}$ \\
\hline Other foods & Tobacco, flavored tobacco, e-cigarettes \\
\hline Nonfood goods/services \\
\hline $\begin{array}{l}\text { Tobacco/e- } \\
\text { cigarettes }\end{array}$ & Check cashing, telephone cards, ATM, lottery tickets \\
\hline Other services & Product promotion, health promotion, advertising \\
\hline Store characteristics \\
\hline Food-related & $\begin{array}{l}\text { Product quality, product placement, product pricing, } \\
\text { local foods, culturally acceptable foods, checkout area, }\end{array}$ \\
\hline $\begin{array}{l}\text { Marketing- } \\
\text { related }\end{array}$ & Product \\
\hline $\begin{array}{l}\text { Store } \\
\text { environment }\end{array}$ & Cleanliness, aesthetics, number of registers \\
\hline $\begin{array}{l}\text { Financial } \\
\text { accessibility }\end{array}$ & $\begin{array}{l}\text { Accept SNAP, accept WIC, accept credit cards } \\
\text { community participation, wheelchair-accessibility }\end{array}$ \\
\hline $\begin{array}{l}\text { Community } \\
\text { issues }\end{array}$ \\
\hline
\end{tabular}

\section{Results}

Twenty-five unique evaluation tools were reported via online survey $(n=14)$ or email to the author $(n=11)$. Of these, 5 were excluded because they did not provide sufficient information to extract summary data for comparison. Only 1 evaluation tool was externally validated (4), whereas others were created or compiled by local researchers or managers. Among types of methods, in-store observations or audits were most prevalent $(\mathrm{n}=11)$, followed by consumer interviews $(\mathrm{n}=5)$, and owner/manager interviews $(\mathrm{n}=$ 4). On average, by type of method used, in-store observations or audits had 25.7 items (standard deviation [SD], 14.4), consumer interviews had 24.6 items (SD, 13.3), and owner/manager interviews had 12.5 items (SD, 13.3).

Evaluation tools collected information on an average of 22.8 items (SD, 14.2), with fruits and vegetables, beverage, and store characteristic categories having the highest average number of items (Figure 1). Of the 20 evaluation tools, 18 included beverage items and/or fruits and vegetables and 16 included some type of assessment of store characteristics.

The opinions expressed by authors contributing to this journal do not necessarily reflect the opinions of the U.S. Department of Health and Human Services, the Public Health Service, the Centers for Disease Control and Prevention, or the authors' affiliated institutions. 


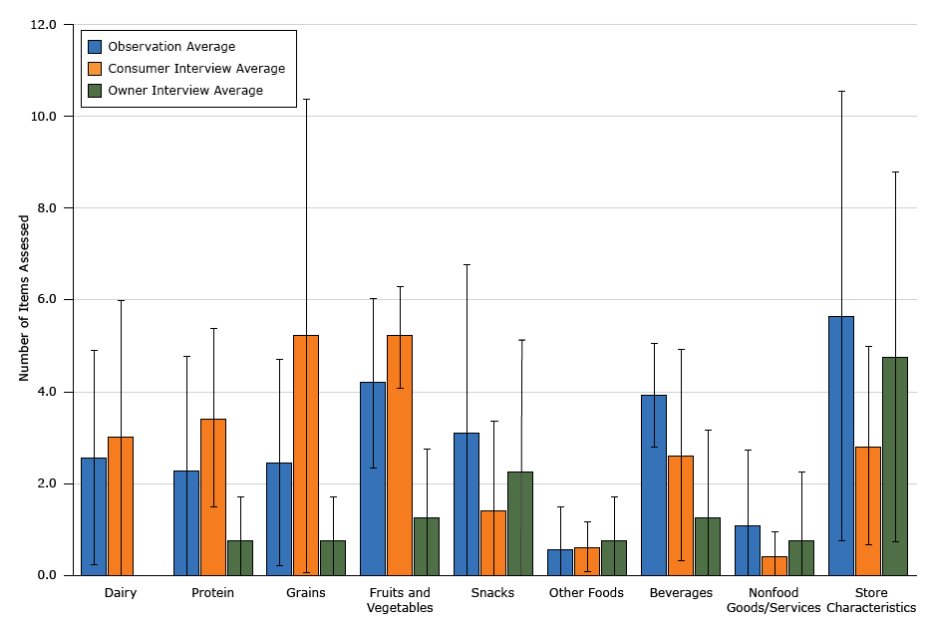

Figure 1. Average number of items assessed in evaluations of healthy corner stores, by type of method used, San Francisco Bay Area, 2016. None of the owner interviews assessed dairy, so no bar appears for that item. Error bars indicate standard deviation.

Nutritional language or standards varied by subcategory of food (Table). For example, one tool applied standards for sugar content in yogurt ( $\leq 13 \mathrm{~g}$ sugar for children's yogurt, $\leq 20 \mathrm{~g}$ sugar for others), while others only recorded its presence or absence. Disagreement between nutrition claims was not widespread, though exceptions existed; for example, grain and snack food categories included multiple definitions of allowable sugar content. When presented to the stakeholder group, many of these findings appeared to be consistent with practitioner observations and generated questions for future research.

\section{Discussion}

Study results clarify the role of various evaluation tools for various purposes: establishing objective baseline conditions, documenting changes, and ensuring compliance with program goals (observational tools); understanding individual and communitylevel perceptions and attitudes about foods and retailers and gathering insights about neighborhood needs (customer interviews); and characterizing the uptake and sustainability of in-store interventions (owner interviews). Validated observational measures were reported by 3 counties (eg, the California Department of Public Health's $\mathrm{CX}^{3}$ tool (4)), and standardized, nonvalidated instruments were used by 5 counties (eg, Center for Science in the Public Interest's healthy checkout audit [6]). This study's findings suggest that greater standardization and documentation of rigorous methods could be useful but would entail additional costs (eg, staff time, training).
To compare results and assess impact at a regional level, disagreements within item categories and between evaluation classes must be addressed. Across the 3 types of evaluation tools, the number of items varied most ( $\mathrm{SD}>3.0)$ for store characteristics, grains, and snacks. Regional stakeholders have already initiated an effort to codify nutritional standards with a focus on snacks. This study provides additional motivation for similar work and identifies other possible priority areas for standardization.

This study has several limitations. Although efforts were made to reach all area stakeholders, some evaluation tools may have been excluded. Generalizability may also be limited to areas where political or logistical realities are amenable to similar stakeholder engagement.

To understand and compare standards in various methods of evaluating healthy corner stores in the 9-county Bay Area, it was necessary to take stock of existing evaluation tools. This study identified 3 general classes of evaluation tools and the categories and subcategories of items these tools recorded. This information may be useful in future collaboration or pooling of data. Insights from this study provide additional motivation for coordination in establishing regional standards.

\section{Acknowledgments}

The author thanks the Bay Area Healthy Retail Committee for their participation and support of this exploratory research. This work was supported by National Institutes of Health/National Heart, Lung, and Blood Institute grant no. T32 HL007034.

\section{Author Information}

Benjamin Chrisinger, PhD, Stanford Prevention Research Center, Stanford University School of Medicine, 1070 Arastradero Rd, Suite 300, Palo Alto, CA 94304. Telephone: 650-497-8000. Email: chrisinger@stanford.edu.

Author Affiliations: ${ }^{1}$ Stanford Prevention Research Center, Stanford University School of Medicine, Palo Alto, California.

\section{References}

1. Gittelsohn J, Rowan M, Gadhoke P. Interventions in small food stores to change the food environment, improve diet, and reduce risk of chronic disease. Prev Chronic Dis 2012;9:E59.

2. Glanz K, Sallis JF, Saelens BE, Frank LD. Nutrition Environment Measures Survey in stores (NEMS-S): development and evaluation. Am J Prev Med 2007; 32(4):282-9.

The opinions expressed by authors contributing to this journal do not necessarily reflect the opinions of the U.S. Department of Health and Human Services, the Public Health Service, the Centers for Disease Control and Prevention, or the authors' affiliated institutions. 
3. Pitts SBJ, Bringolf KR, Lawton KK, McGuirt JT, Wall-Bassett E, Morgan J, et al. Formative evaluation for a healthy corner store initiative in Pitt County, North Carolina: assessing the rural food environment, part 1. Prev Chronic Dis 2013; 10:E121.

4. Ghirardelli A, Quinn V, Sugerman S. Reliability of a retail food store survey and development of an accompanying retail scoring system to communicate survey findings and identify vendors for healthful food and marketing initiatives. J Nutr Educ Behav 2011;43(4,Suppl 2):S104-12.

5. Gittelsohn J, Laska MN, Karpyn A, Klingler K, Ayala GX. Lessons learned from small store programs to increase healthy food access. Am J Health Behav 2014;38(2):307-15.

6. Fielding-Singh P, Almy J, Wootan MG. Sugar overload: retail checkout promotes obesity. Washington (DC): Center for Science in the Public Interest; 2014. https://cspinet.org/sites/ default/files/attachment/sugaroverload.pdf.

The opinions expressed by authors contributing to this journal do not necessarily reflect the opinions of the U.S. Department of Health and Human Services, the Public Health Service, the Centers for Disease Control and Prevention, or the authors' affiliated institutions. 


\section{Table}

Table. Nutritional Vocabulary Used in Healthy Corner Store Evaluation Tools in the 9-County San Francisco Bay Area Region As of December 2016

\begin{tabular}{|c|c|c|}
\hline \multicolumn{2}{|c|}{ Product Category/Subcategory } & Nutritional Language or Standard \\
\hline Dairy & Milk & $\begin{array}{l}\text { - Reduced fat } \\
\text { - } 2 \% \\
\text { - } 1 \% \\
\text { - Low-fat or skim } \\
\text { - Skim } \\
\text { - No added sugar } \\
\text { - Unflavored }\end{array}$ \\
\hline & Milk alternative ${ }^{b}$ & $\begin{array}{l}\text { - No added sugar/sweetener } \\
\text { - Unflavored }\end{array}$ \\
\hline & Cheese $^{\mathrm{c}}$ & $\begin{array}{l}\cdot \text { Skim } \\
\text { - Low-fat } \\
\cdot 1 \%\end{array}$ \\
\hline & Yogurt $^{\mathrm{C}}$ & $\begin{array}{l}\text { - Low fat } \\
\text { - Children's: } \leq 13 \text { g sugar/serving } \\
\text { - Non-children's: } \leq 20 \text { g sugar/serving }\end{array}$ \\
\hline \multirow[t]{2}{*}{ Protein } & Meat & $\begin{array}{l}\cdot \leq 15 \% \text { fat } \\
\cdot \text { Fresh } \\
\cdot \text { Skinless }\end{array}$ \\
\hline & Nut butter ${ }^{\mathrm{C}}$ & $\begin{array}{l}\text { - Unsweetened } \\
\text { - No added oils } \\
\text { - Nonhydrogenated }\end{array}$ \\
\hline \multirow[t]{2}{*}{ Grain } & Cereal & $\begin{array}{l}\text { - First ingredient whole grain, }<9 \text { g sugar/serving } \\
\text {-Whole grain, }<7 \text { g sugar } \\
\cdot<7 \text { g sugar or }>10 \% \text { daily value of fiber } \\
\cdot \geq 3 \text { g fiber, } \leq 12 \text { g sugar }\end{array}$ \\
\hline & Bread & $\begin{array}{l}\cdot \geq 10 \% \text { daily value of fiber, whole grain first ingredient } \\
\cdot \text { Whole wheat } \\
\cdot 100 \% \text { whole grain } \\
\text { - Gluten-free }\end{array}$ \\
\hline \multirow[t]{5}{*}{ Fruits and vegetables } & Vegetable, canned & $\begin{array}{l}\cdot<290 \mathrm{mg} \text { sodium/serving } \\
\cdot \leq 140 \mathrm{mg} \text { sodium } \\
\cdot \text { - In water } \\
\text { - No added fat, sugar, sweetener }\end{array}$ \\
\hline & Vegetable, fresh & Does not count potatoes or onions; $\geq 1$ dark leafy green (does not count iceberg lettuce) \\
\hline & Fruits and vegetables, frozen & $\begin{array}{l}\text { - No added fat, sugar, or sweetener } \\
\text { - No added sauce/sugar }\end{array}$ \\
\hline & Fruit, canned & $\begin{array}{l}\text {-100\% juice, no added sugar/syrup } \\
\text { - Nonsyrup } \\
\text { - No sugar added, no syrup/sauce }\end{array}$ \\
\hline & Fruit, fresh & Does not count lemons and limes \\
\hline
\end{tabular}

${ }^{a}$ Some of the nutritional vocabulary used in this table is nonstandard and reflects wording used in a healthy corner store evaluation or locality.

${ }^{\mathrm{b}}$ Milk alternatives, such as soy and almond milk.

${ }^{\mathrm{c}}$ Subcategory amended to identify object of nutritional language or standard. 
(continued)

Table. Nutritional Vocabulary Used in Healthy Corner Store Evaluation Tools in the 9-County San Francisco Bay Area Region As of December $2016^{a}$

\begin{tabular}{|c|c|c|}
\hline \multicolumn{2}{|c|}{ Product Category/Subcategory } & Nutritional Language or Standard \\
\hline Snack food & Snacks & $\begin{array}{l}-\leq 230 \mathrm{mg} \text { sodium; } \leq 13 \mathrm{~g} \text { sugar } \\
\text { - Fruit or vegetable based, healthy protein based, whole grain, dairy based; local } \\
\text { - Whole grain ( } \geq 2 \mathrm{~g} \text { fiber) } \\
\cdot<10 \text { g sugar, }<10 \% \text { daily value of fat }\end{array}$ \\
\hline & Bars & $\begin{array}{l}\text {-Whole grain, } \geq 2 \mathrm{~g} \text { fiber, } \leq 1 \mathrm{~g} \text { saturated fat, } \leq 14 \mathrm{~g} \text { sugar } \\
\text { - Energy bars ( } \leq 14 \text { g sugar) }\end{array}$ \\
\hline & Nuts and seeds & No added sugar, not honey-roasted \\
\hline & Popcorn $^{c}$ & Low-fat/no butter \\
\hline & Chips and pretzels & Baked \\
\hline \multirow[t]{3}{*}{ Beverages } & Water & $\begin{array}{l}\text { - Calorie-free flavored, plain, mineral, or seltzer } \\
\text { - Carbonated (no sugar), plain (unflavored) }\end{array}$ \\
\hline & Juice & $\begin{array}{l}\text {-100\% fruit juice } \\
\text { • Unsweetened }\end{array}$ \\
\hline & Non-sugar-sweetened & $\begin{array}{l}\text { - No added sugar } \\
\text { - } 0 \text { g sugar }\end{array}$ \\
\hline \multirow[t]{2}{*}{ Other food } & Frozen meals & $<800 \mathrm{mg}$ sodium, $<8 \mathrm{~g}$ fat \\
\hline & Prepared foods ${ }^{c}$ & Healthy sandwiches \\
\hline
\end{tabular}

${ }^{\text {a }}$ Some of the nutritional vocabulary used in this table is nonstandard and reflects wording used in a healthy corner store evaluation or locality.

${ }^{\mathrm{b}}$ Milk alternatives, such as soy and almond milk.

${ }^{\mathrm{c}}$ Subcategory amended to identify object of nutritional language or standard. 